\title{
Strengthening Implementation of the Justice Restorative Justice in the Perspective of Law Number 16 Year 2004 on the Judiciary and Islamic Law
}

\author{
Sugianto ${ }^{1}$, Wahyu Oktaviandi ${ }^{2}$ \\ ${ }^{1}$ Graduate Lecturer of IAIN Sheikh Nurjati Cirebon \\ ${ }^{2}$ Master of Law Students Postgraduate IAIN Sheikh Nurjati Cirebon \\ Corresponding Author: Sugianto
}

\begin{abstract}
Restorative Justice is an approach to justice that focuses on the needs of the victims and perpetrators of crime, as well as involving the community, not to follow the principle of punishment for the perpetrators accompanied by the consideration of the judges. The principle of Restorative Justice process of the completion of the action a violation of law that occurs is done by bringing victims and offenders together talking. The act of punishment alternative to using the justice restorative should be pursued by the state so that the adhesion of unity of the nation become strong and become potential of socio-economic development and politics of the country. The propriety of the imposition of a criminal through the justice restorative so the duty and responsibility of law enforcement to sharpen legal analysis and sensitive conscience of humanity. justice restorative aims to reconcile the conflicting parties. If offenders could be rehabilitated with other measures that better then the punishment should be avoided. In the penalty ta'zir, forgiveness and granting the minimum penalty is the criminal justice system of Islam that can change the penal system of retributive to restorative. This research problem is how the strengthening of restorative justice in the settlement of the criminal case according to Law Number 16 Year 2004 On the Prosecutor's office? How the actualization of the completion of the criminal case through the restorative justice perspective of Islamic Law? The purpose of this study was to determine the strengthening of restorative justice in the settlement of the
\end{abstract}

criminal case according to Law Number 16 Year 2004 On the Prosecutor's office and find out the actualization of the completion of the criminal case through the restorative justice perspective of Islamic Law. Methods this research was conducted using qualitative research a research process and understanding based on the methodology that investigates a phenomenon of social and human problems. The results of this study concluded, that the strengthening of restorative justice in the settlement of the criminal case according to Law Number 16 Year 2004 On the Prosecutor's office through a mediation that can be used in resolving a criminal case. A new breakthrough in the Indonesian criminal justice system in the completion of a criminal offence outside the court.

Keywords: Strengthening of Justice, Restorative Justice, Attorney General and Islamic Law

\section{INTRODUCTION}

Efforts to control crime with the use of criminal sanctions is the most commonly encountered included in the system of criminal law Indonesia, as stated by the Barda Nawawi Arief, who take the opinion of the Gene Kassebaum stated that the crime prevention with the use of criminal sanctions is the way that most of the old, as old as human civilization itself. Herbert L. Packer also suggested that the control of anti-social act by using criminal on someone 
who is innocent is a social problem that has a legal dimension that is important.

Indonesia is a country of laws, it has been described in Article 1 paragraph (3) of the Basic Law (Constitution) 1945, which states that Indonesia is a country of law, it is based on the explanation of the 1945 constitution that the state of Indonesia based on law (rechtstaat) and not based on sheer power (machstaat). The state should not carry out activities on the basis of sheer power, but it must be based on law, in the settings, to the people that carried out by the government basing on the Law of the State Administration.

Criminal law is the whole of the law applicable in a country, which hold the basics and rules, to determine the deeds which should not be done, is prohibited, accompanied by threats or sanctions in the form of certain criminal for anyone who violates the ban. Determine when and in what terms to those who have violated the prohibitions, it can be charged or sentenced as promised. Determine how the imposition of a criminal it can be done, if there are people suspected to have violated the ban.

Criminal law is the ultimum remedium in the settlement of a dispute that arose in the community. Criminal law ditafisrkan as a last-ditch effort that can only be dropped if the enforcement mechanism other lighter has been powerless to or viewed is not adequate. In its development to provide reinforcement that criminal law is the ultimum remedium, then the development of the concept of justice restorative justice is born. The concept of restorative justice underlined the fact that the purpose of criminal proceedings is to restore justice. Justice restorative present as a form of approach settlement according to the criminal law involving the perpetrator of the crime, the victim, the victim's family, or the offender and other relevant parties to seek a fair settlement with emphasis on the recovery back in its original state.

In Indonesia, the actual restorative justice is not a new concept because the concept of customary law in Indonesia as a container of the institution of customary justice also has a concept which can be described as the roots of restorative justice. Characteristics of customary law in each area is generally very support the implementation of restorative justice. It can be seen from the general characteristics of customary law in Indonesia, the outlook for the customs violation/offense customs as well as the model and the settlement offered.

Restorative justice does not solely apply a decision about who wins and who loses in the criminal justice system that is hostility/resistance (adversarial system), the process of restorative justice look for a dialogue between all parties affected by crime, including the victim, the offender, their supporters, and the community as a whole. This involves a process whereby all parties at risk in a particular crime jointly endeavor to resolve collectively how to deal with after the occurrence of the crime and its implications in the future.

The process of handling a criminal case is conducted in stages and gradually. As for the stages of the process of handling a criminal case is done in a series system consisting of the Investigation process (Opsporing), Prosecution (Vervolging), the Court (Rechtspraak), the Implementation of the Verdict of the Judge (Executie), and the Supervision and observation of the court ruling. A series of system the known as the Criminal Justice System. One of the most important process is the process of prosecution. Institutions that carry out the process of the prosecution in Indonesia is the Institution of the Prosecutor's office. The prosecutor's office has position of the central and the part that is located in a country of law, especially in the Indonesian criminal justice system because of the institution of the Prosecutor's office into the Filters (filter) between the process of investigation and inspection process. That the Prosecutor's office that determine the rise or whether or not a court case (controller case or the Dominus litis). 
The institution of the Prosecutor's office is an institution which has the duty and authority are very complete, but in the application (implementation) of the field, the prosecutor's office is often considered the lack of acceleration in the process of handling a case, proved to be one of the background in such problems is the presence of several things that are not completely in the handling of the case in the institution of the prosecutor's office. Look at the fact still the buildup of the case in the court of law, the inequality of the budget handling of the case as well as the handling of the case (in Criminal Law in Indonesia) inefficiency (in the sense of not recognizing the presence of a special line in the handling of the case) then it is a new hope for the law of criminal procedure Indonesia by entering the process of restorative justice as a solution to the efficiency of a case handling. Therefore, interesting for us to discuss together how the concept of restorative justice can be a solution for the efficiency of the handling of the criminal case and also the strengthening of the function of the prosecutor's office.

Restorative justice is an alternative to the completion of the criminal case that in the mechanism of the ordinances of the criminal justice focuses on the punishment that is converted into a process of dialogue and mediation involving the offender, the victim, the family of the perpetrator/victim, and other relevant parties to work together to create an agreement on the settlement of a criminal case that is fair and balanced for the victim or the offender by promoting the recovery back to the original state, and restore the pattern of good relations in the community. Basic principles of restorative justice are the presence of a recovery to the victims who suffer the consequences of crime by providing redress to the victims, peace, actors do social work and the agreements of the other. The law fair in restorative justice is certainly not biased, impartial, not arbitrary, and only on the side of truth according to the rules of the applicable legislation as well as considering the equality of rights of compensation and balance in every aspect of life.

This is evidenced by the presence of crowded institutions law enforcement, namely the Indonesian national Police, the Prosecutor's office of the Republic of Indonesia, and the Supreme Court of the Republic of Indonesia, issuing internal regulations concerning the settlement of the case outside of court using the approach of restorative justice. Political law is emerging as a reaction to the rise of criminal cases classified as misdemeanors brought into the realm court. Misdemeanor referred to in this study is that the crime can be solved by means of peace and not interrupt existing social conditions.

As evidence that these institutions above is committed to applying legal remedies with the use of restorative justice is the example of case occur in time ago when the case of the grandmother Minah who stole three cocoa fruit that has fallen from the tree. The case being so, that should be resolved amicably, but because it can not control the emotion of a moment, the actions of the grandmother then reported to the police with charges of stealing. Eventually, the grandmother received criminal sanctions of the court.

With its internal regulations issued by law enforcement was immediately responsive to the realities of the law, namely the Circular Letter of the Chief of Police of the Republic of Indonesia No:SE/8/VII/2018Tanggal 27 July 2018 On the Application of Restorative Justice In the Completion of the Criminal Case, the Regulations of the Prosecutor's office of the Republic of Indonesia Number 152020 About the Termination of the Prosecution Based on Restorative Justice and the Decision of the Director General of the General court of the Supreme Court of the Republic of Indonesia No: 1691/DJU/SK/PS.oo/12/2020 December 22, 2020 About the Implementation of Guidelines for the Application of Restorative Justice. 
Restorative Justice is an approach to justice that focuses on the needs of the victims and perpetrators of crime, as well as involving the community, not to follow the principle of punishment for the perpetrators accompanied by the consideration of the judges. The principle of Restorative Justice process of the completion of the action a violation of law that occurs is done by bringing victims and offenders together talking. Restorative Justice is an approach to justice that focuses on the needs of the victim and the offender, and the community involved, not to follow the principle of punishment for the perpetrators.

According to Bagir Manan, that the barriers in implementing the peace between the victim and the perpetrator is often rooted in the attitude of law enforcement very formalistic by saying the legal process will keep running though the peace, the nature against the law will not be deleted because of the peace.

\section{LITERATURE REVIEW}

The Concept Of The Completion Of The Criminal Case Outside The Court

\section{The Mediation Panel}

According to the great Dictionary of the Indonesian Mediation is a process of settlement of a matter involving a third party. Mediation is a process of negotiations/ negotiating in problem solving, where parties who are not impartial in collaboration with the disputing parties to seek and find a mutual agreement.

\section{ADR (Alternative Dispute Resolution)}

The concept of ADR (Alternative

Dispute Resolution) emphasizes the settlement of disputes by consensus that has long been made public, which emphasized the efforts of deliberation, kinship, peace and so on. ADR has a special appeal because keserasiannya with the social system of traditional culture based on consensus.

\section{MATERIAL AND METHODS}

This research is a Library Research. The research literature, namely "the research conducted by using literature, either in the form of note books, and research reports of previous research". Through this method the writer is trying to collect the data needed with the way looking for opinions and theories relevant with the issues contained in this thesis to be a source of reference in the effort to complete the writing.

Legal research is normative juridical, as to the form of normative juridical research is legal research that is done by researching library materials. This research is analyzed by using the descriptive analytical method, namely by means of analyzing the data are examined by describing the data, and then obtain the conclusion.

The source of the Data That is material in a legally binding form of book related to this research is that book about the criminal law, the book of the law of criminal procedure, a book about law enforcement, the book of restorative justice, criminal code, criminal procedure code, Law No. 16 of 2004 On the Prosecutor's office.

Technical Analysis of the Data as a data collection is a process, procedure or method used to solve a problem that will be studied. In the study of the juridical normative can be limited in the use of library studies or library materials only. Data have been obtained by using the method of the research literature and then analyzed with the Inductive method, namely "the way of thinking of the fact-the fact of a special nature, the events of the concrete then from the facts and events that concrete is drawn conclusions that are common”.

\section{RESULTS AND DISCUSSION Restorative Justice}

The concept of restorative justice is a concept in which victims and perpetrators are equally involved in the resolution of problems that pose doubt for the victims. So 
the concept of this constructively will resuscitate a child that carry out criminal acts will be their fault, in other words, the offender will be aware that the criminal is a liability instead of retaliation.

According to the Muladi, restorative justice or restorative justice is a theory that emphasizes the recover loss caused or inflicted by the criminal act. To recover these losses will be achieved with the process of cooperative that includes all interested parties. The concept of restorative justice is focused on the condition of the creation of justice and balance to the criminal and the victims themselves. The mechanism of the ordinances of criminal justice that focuses on the punishment be transformed into a process of dialogue and mediation to create an agreement on the settlement of a criminal case that is fair and balanced for the victim and the offender.

The approach used to achieve justice restorative is pursue the process of mediation between the victim and the offender, the meeting and dialogue between the victim and the perpetrator involving the family and the wider community, and cultivate an awareness of the perpetrator and the victim. The main spirit of restorative justice is not only to prosecute or punish the offender but to repair and restore the victims and the perpetrators. Then the value of restorative justice is located on the dialog (dialogue), understanding (mutuality), healing, repair, regret and repentance, responsibility, honesty and sincerity.

In restorative justice victim taken into account his dignity, and the perpetrators should be held accountable and integrated back in the community. The offender and the victim is a resident of balanced and need each other, because it should be dirukunkan. The position of the cause of justice restorative should be changed, is no longer in the interests of order, but for the sake of the interests of victims and their recovery in terms of material and psychological. So, to be realized in the justice restorative justice is to prevent the offender from imprisonment, and to be responsible for his actions.

Restorative justice is a traditional concept that has been practiced in some countries, especially in parts of the Eastern world. The concept is believed as an alternative in order to reduce the undesirable excesses as a result of the implementation of the criminal justice system formally. The conception has been run and is applied in other countries and it is believed as an alternative to avoid the negative effects the use of a formal system of judicial institutions which sometimes produce something that is unwelfare in order to protect the legal interests of the parties.

According to $\mathrm{PBB}$, the program justice restorative justice is a program that uses the restorative process with the target to achieve the desired results. The main goal of such models is to restore peace and a relationship that is damaged through reproaches against the perpetrators of the evil and strengthen the values that live in society. The victim noticed his needs and the actors are encouraged to be responsible.

Restorative justice appears as triggered dissatisfaction with the Criminal Justice System conventional and rooted in the practices of the natives. Restorative justice is used against evil, discipline in school and various other conflicts between citizens and government, the Commission of the Treaty of Waitangi in New Zealand.

Restorative justice refers to the ways traditional, customary and religious conflict related, but the effectiveness of the practice of justice restorative often rely on the criminal justice system a well functioning and credible. Emphasis renewal on restorative justice is often based on the view that the state is no longer considered as the only source to realize the justice of effective and fair. The concept of restorative justice can also be viewed as the search for new alternative in resolving cases in a reconciliatory by involving the victim, the offender, and the community. This concept is managed effectively complete a few cases 
are classified mild to major cases such as murder.

\section{Criminal}

Crime is any act or series of acts that may be charged penalties or criminal sanctions. However, the criminal law of the netherlands term wear strafbaar feit, sometimes also delict which is derived from the latin Delictum. And therefore, the Book of the law of criminal Law Indonesia is based on the WvS Dutch, hence the term the original was the same, namely strafbaar feit.

The threat of criminal sanctions against the actions of the crime or the criminal is as a consequence of an act that is considered detrimental to society and which should be avoided, according to the intent of the legal order. In line with the explanation that some experts argue about the meaning of the criminal:

a. Simons: an act or deed punishable by criminal law, contrary to the criminal law and is done by mistake by someone who is able to be responsible.

b. Pompe: the violation of norms (disruption to the order of law) deliberately or by accident has been committed by a perpetrator, where the imposition of penalties against the perpetrators of such is necessary for the maintenance of the rules of law and ensuring the interests of the law.

c. E.Utrecht: Understanding Criminal by fill in the criminal event which is often also he calls the offense, because of the events that an act (handelen or doen positive) or shirk (natalen-negative), and consequently (a condition which is caused due to the act or neglect it).

Moeljatno use the term criminal act as a translation of strafbaarfeit and give the following definition: "Criminal act is prohibited by a rule of law, the prohibition of which accompanied the threat of sanctions (in the form of certain criminal for anyone who violates the ban)".

The term strafbaarfeit also translated by R. Soesilo as follows: "Crime as a term of offense or criminal event or act that can be punished, namely as an act that is forbidden or required by law that, if done or ignored, then people who do or neglect will be threatened with a criminal".
While
Bambang
Poernomo (1982:90) states that: "In the Book of the law of Criminal Law is known by the term straafbaarfeit. The literature on the law of criminal often use the term offense while lawmakers in formulating strafbaarfeit use the term criminal irrespective of the difference in those terms".

More Bambang Poernomo explains that the term offense. Strafbaarfeit, the events of the criminal and criminal and criminal act, have the same sense that an act which is prohibited by the rule of law and the ban is accompanied with threats and sanctions in the form of a criminal who violated the ban.

According to Bambang Poernomo first express the meaning as "Tatbestandmassigheit" is a behavior that do match the painting and the provisions outlined in the legislation concerned.

\section{The Prosecutor's Office in the Law Number 16 Year 2004}

Prosecutor's regulated in Law Number 16 Year 2004 on the Prosecutor's office of the Republic of Indonesia. Based on Article 1, point 1 legislation Law Number 16 Year 2004 on the Prosecutor's office of the Republic of Indonesia that the Prosecutor is functional officials authorized by law to act as a public prosecutor and implementing the verdict of the court which has obtained the force of law and other authority under the act. Whereas Article 2, point 1 of Law Number 16 Year 2004 on the Prosecutor's office of the Republic of Indonesia that the Prosecutor's office of the Republic of Indonesia is government agencies that implement the power of the state in the field of prosecution and other authorities under the act. From the formulation of the article, Ladeng Marpaung conclude that the Prosecutor's office is:

a. Government agencies. Thus, the Prosecutor's office, including the 
executive, not the legislative, and not judicial.

b. Carry out the power of the state; thus, the Prosecutor's office is the state apparatus.

Meanwhile, according to the view of the thinking of scholars Prosecutor's Dr. Saheroji, explain the origin of the word from the prosecutor that "the Word attorney comes from sanskrit which means the superintendent or the controller, i.e. the supervisory about community."

The prosecutor's office is a government agency that carries out the state power, especially in the field of prosecution in the arrangement of the powers of law enforcement agencies and justice, led by Attorney general who is directly responsible to the President. In Indonesia, the Prosecutor's office of the Republic of Indonesia is one of the law enforcement agencies that his position was in the power of the government which serves to carry out the powers of the state in the field of prosecution under Article 2, paragraph (1) of Law Number 16 Year 2004 on the Prosecutor's office of the Republic of Indonesia, disampingmelaksanakan the function of other powers by the legislation. The Functions Of The Prosecutor's Office include:

"Aspects of preventive and aspects of the repressive in the penal law as well as State's Attorney in the Civil and State administration. Aspects of Preventive, in the form of increased legal awareness, security policy enforcement, security, circulation bang moulds, control the flow of the trust, the prevention of abuse and/or desecration of religion, the research and development of the law as well as the statistics of crime. Aspects of the repressive conduct the prosecution in a criminal case, carry out the determination of the Judge and the verdict of the court, monitoring the implementation of the decision of the conditional release, complete the case file of a certain derived from the investigating Police or Civil servant Investigator.”
In carrying out the powers of the state are implemented in independent and is a part that can not be separated. The prosecutor's office as one of the law enforcement agencies required a more important role in upholding the rule of law, protection of the interests of the public, the enforcement of human rights, and the eradication of corruption, collusion and nepotism.

Based on Article 1, point 6 of Law No. 8 of 1981 on Criminal procedure Law that:

a. The prosecutor is an official who is authorized by law to act as a public prosecutor as well as carry out the verdict of the court which has obtained the force of law.

b. The public prosecutor is the attorney that is authorized by this act for the conduct of the prosecution and to carry out a judge's ruling

\section{CONCLUSIONS AND RECOMMENDATIONS}

\section{Conclusion}

1. Prosecutor's office of the Republic of Indonesia Law no. 16 of 2004 as a Government Institution, with the authority of the Prosecution and other authorities who administered the Law, in carrying out the Prosecution of a Criminal offence under, Justice Restorative Justice.

2. In the Regulations of the Prosecutor's office of the Republic of Indonesia Number 152020 About the Termination of the Prosecution Based on Restorative Justice that the Position of the Prosecutor's office as a Law Enforcement Agency through an Approach that is used to realize the restorative justice as the Efforts of the mediation process.

3. In carrying out the powers of the state are implemented in independent and is a part that can not be separated. The prosecutor's office as one of the law enforcement agencies required a more important role in upholding the rule of 
law, protection of the interests of the public, the enforcement of human rights, and the eradication of corruption, collusion and nepotism.

\section{Recommendations}

1. Needs to be made the legalization of the completion of the criminal case in a specific outside the court. Every guilty person should indeed be punished, but should be considered also from a sociological aspect, that need to be made a legal alternative for specific criminal acts that not all cases go to court, this will certainly reduce the buildup of cases in court.

2. Since in the investigation should have been offered a peaceful settlement, in which the offender apologized to the victims and their families as well as replace losses suffered. When there has been peace like this, then it is not necessary the case proceed to trial.

\section{Acknowledgement: None}

\section{Conflict of Interest: None}

\section{Source of Funding: None}

\section{REFERENCES}

1. Abdoel Jamali, 2012, Pengantar Hukum Indonesia, Jakarta: Rajawali pers.

2. Abdul Khadir Muhammad, 2016. Hukum dan Politik Hukum. Citra Ditya Bakti, Bandung.

3. Ali zaidan dalam bunga rampai Komisi Yudisial, 2007, Kontribusi Lembaga Kejaksaan Dalam Mempercepat Reformasi Peradilan.

4. Andi Hamzah, 1994, Asas-Asas Hukum Pidana, Jakarta: Rineka Cipta.

5. Ansori. 2015, Restorative Justice Menuju Sistem Peradilan Pidana Terpadu, Varia Nomor 350, Ikatan Hakim Indonesia.

6. Dellyana, Shant. 2008, Konsep Penegakan Hukum. Yogyakarta: Liberty.

7. Eva Achjani Zulfa dan Indriyanto Seno Adji, 2011, Pergeseran Paradigma Pemidanaan, Badnung: Lubuk Agung.
8. Evi Hartanti, Tindak Pidana Korupsi, 2005, Semarang: Sinar Grafika.

9. Hans Kelsen, 2008, Teori Umum Tentang Hukum dan Negara, Bandung: Nusa Media.

10. Hans Kelsen, 2013, General Theory Of Law And State, terj. Raisul Muttaqien, Teori Umum Tentang Hukum dan Negara, Bandung: Nusa Media http://www.hukumonline.com/berita/baca/ lt4e25360a422c2/pendekatan-irestorativejusticei-dalam-sistem-pidana-indonesiabroleh--jecky-tengens--sh-,diakses pada tanggal 18 Oktober 2016.

11. I Made Agus Mahendra Iswara, 2012. Penguatan Kejaksaan Dalam Penanganan Perkara Pidana Melalui Plea Barganing, dalam Makalah. Kejaksaan Negeri Flores Timur.

12. Kitab Undang-undang Hukum Acara Pidana.

13. Kitab Undang-undang Hukum Pidana.

14. Ladeng Marpaung. 2011. Proses Penanganan Perkara Pidana (Penyelidikan dan Penyidikan). Sinar Grafika: Jakarta.

15. Lawrence M. Friedman, 2009, Sistem Hukum ; Perspektif Ilmu Sosial(The Legal System ; A Social Science Perspective), (Bandung: Nusa Media.

16. Lawrence M. Friedman; The Legal System; A Social Scince Prespective, Russel Sage Foundation, New York, 1975.

17. Marwan Effendi, 2005, Kejaksaan RI; Posisi dan Funginya dari Perspektif Hukum, Gramedia Pustaka Utama, Jakarta.

18. Maswandi, A. S. (2020). Perampasan Aset Hasil Tindak Pidana Pencucian Uang Dengan Asal Pidana Korupsi. Malang: Mazda Media.

19. Maswandi, A. S. (2020). Tindak Pidana Korupsi Dibalik Kontrak Pengadaan Barang. Jasa, Yogjakarta: K-Media.

20. Moeljatno, 1993, Asas-asas Hukum Pidana, Putra Harsa, Surabaya.

21. Moeljatno. Asas Asas Hukum Pidana, 2008, Jakarta: PT. Rineka Cipta.

22. Moelyatno,2008. Asas-asas Hukum Pidana, Jakarta: Rineka Cipta.

23. Muhammad Ali Zaidan, 2015. Menuju Pembaharuan Hukum Pidana, Jakarta: Sinar Grafika. 
Sugianto et.al. Strengthening implementation of the justice restorative justice in the perspective of law number 16 year 2004 on the judiciary and Islamic law.

24. Sitompul, A. (2020). The Criminal Replacement Of Fine In Law Of Money Laundering Number 8 Of 2010 (Case Study In North Sumatera). International Journal Of Creative Research Thoughts, 8(11).

25. Sitompul, A., \& Sitompul, M. N. (2020, February). The Combination Of Money Laundering Crime With The Origin Of Narkotics Crime To Islamic Law. In Proceeding International Seminar of Islamic Studies (Vol. 1, No. 1, pp. 671681).
26. Sitompul, A., Maswandi (2021). Nikah Poliandri Dalam Perpektif Pidana Islam dan Hukum Positif di Indonesia. Malang: Mazda Media.

How to cite this article: Sugianto, Oktaviandi W. Strengthening implementation of the justice restorative justice in the perspective of law number 16 year 2004 on the judiciary and Islamic law. International Journal of Research and Review. 2021; 8(11): 410-418. DOI: https://doi.org/10.52403/ijrr.20211152 